\title{
GEOMETRIC MODELING OF REFLECTED SOUND WAVES IN THE THREECENTRED ARCH
}

\author{
Ivan Kernytskyy ${ }^{\bowtie}$, Oksana Nikitenko \\ Faculty of Civil and Environmental Engineering, Warsaw University of Life Sciences - SGGW, Warsaw
}

\begin{abstract}
Currently, reflecting systems are widely used in heating equipment, solar engineering structures and acoustic structures. Here, constructions based on classical curves do serve in reflectors. The reflection trajectories represent such curves as podera, orthotomic and caustic paths. Research goal to find an analytical description of the threecentred curve, its podera and orthotomics, and to build a reflecting geometric model of the existing this arch. Such curves' analytical description has been carried out using analytical geometry on the plane. First, we derived podera and orthotomics formulas for a circle, and then for the threecentred arch properly. For the geometric modeling of reflected sound waves in the threecentred arch, we selected the existing arch, this one of the Yusupov Palace Trapeznaja Palata. The subject arch graphic representation has been build in the AutoCAD editor, including the structure of arch properly, its podera, orthotomics and caustic for its threecentred part. Results obtained actually affirmed the proficient acoustic phenomena knowledge appropriate to the ancient architects capable to apply correctly in practice their skills.
\end{abstract}

Key words: threecentred arch, podera, orthotomics, caustic, envelope

\section{INTRODUCTION}

Currently, reflecting systems are widely used in heating equipment, solar engineering structures and acoustic structures. Here, constructions based on classical curves do serve in reflectors; for the reason of better understanding and therefore evaluation of the "reflection quality", their optical geometric properties are subject to investigation. When reflecting, trajectories represent such curves as podera, orthotomic and caustic paths. Such objects geometric modeling is widely represented at such scientific works as Pidgornyi and Kutsenko (1999) and Tutunnikov (2013).

With sufficient certainty, we can say that all frequently used classical curves are, at least, analytically described with poderas graphical shape building.

However, there exists a curve that, from the mathematical point of view, does not represent any scientific interest, since it is only a particular kind of circle (thoroughly studied long time ago): a threecentred curve. Being insignificant for mathematical purposes, this curve acquired extremely applied quality in architecture. For centuries the mankind used it in the form of beautiful arches and vaults (Lewis, 2008). But the most importantly, unlike many others mathematical and classical reflecting curves that still never "detach from the paper", this one does actually serve as a "sound reflecting system". It is for their sound qualities that these arches have won the love of ancient architects.

\section{MATERIALS AND METHODS}

\section{Plotting a threecentred curve with its subsequent analytical description}

The plane curved lines composed of conjugate arcs of circles having different radii, are called threecentred curves.

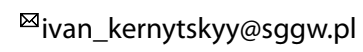


It is seen from the plotting layout that the points $\mathrm{B}$ and $\mathrm{D}$ are these of arcs conjugation to circles with centers $\mathrm{O}_{1}, \mathrm{O}_{2}$, and $\mathrm{O}_{2}$ having respetively radii $r$ and $R$ (Fig. 1), (Rozborski, 2006). To be noted is that also there exist other threecentred curves (for example, the Tudor arch), but we shall limit our study with the aforementioned one.
Let we define the curve arcs radiuses and their centers using the span $(L)$ and the rise height $(H)$ (Fig. 2). For the derived formulas simplicity, we introduce the designation $a$ :

$$
a=\frac{L}{2}-H
$$

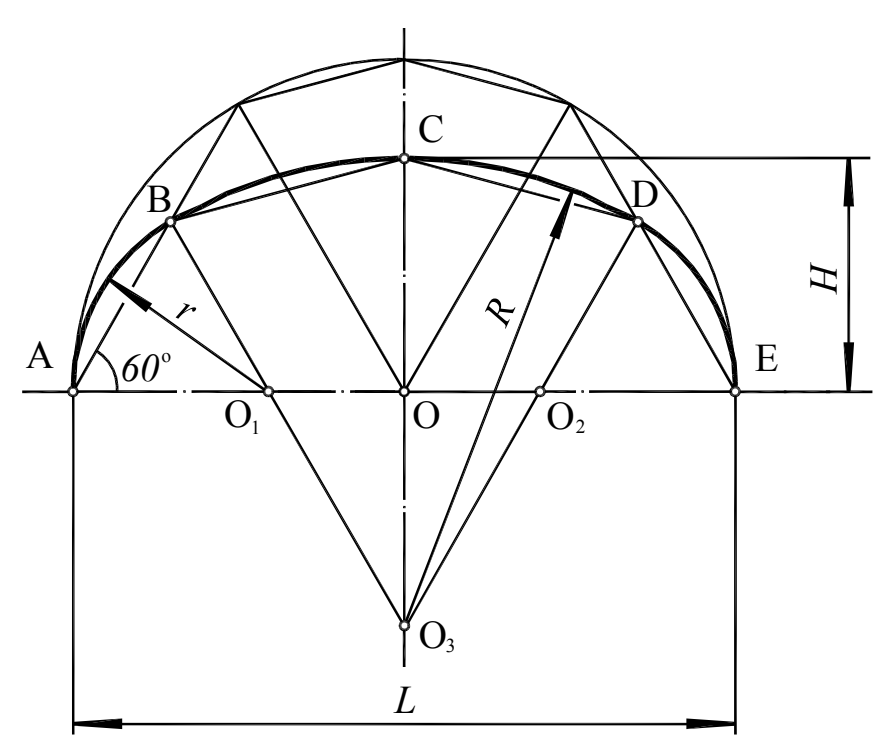

Fig. 1. The threecentred curve structure

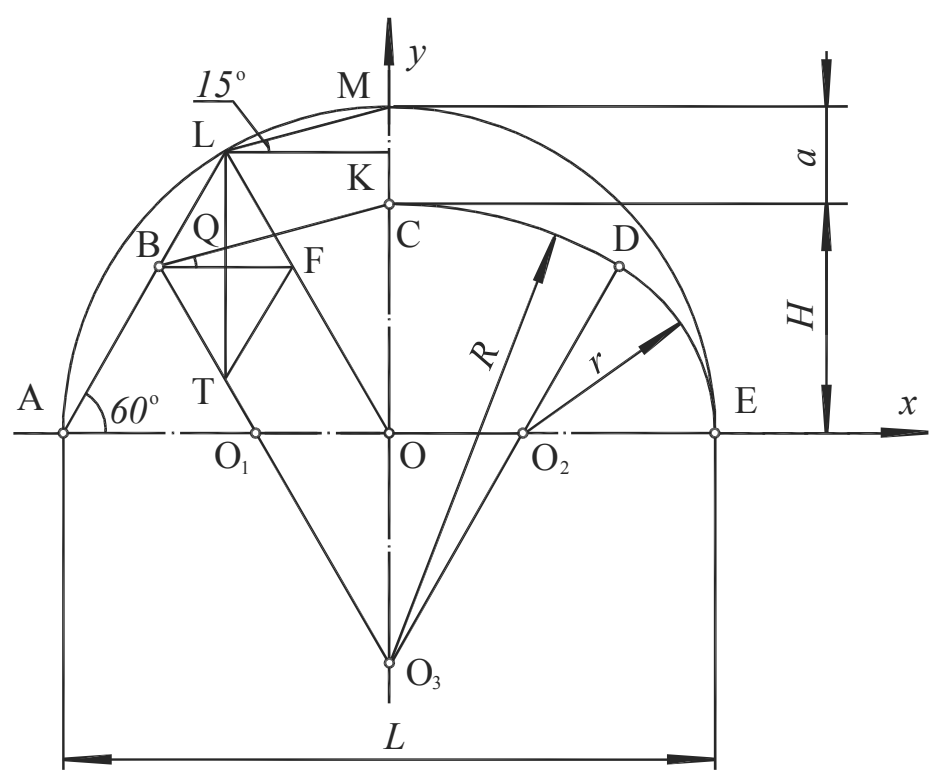

Fig. 2. The threecentred curve structure with auxiliary triangles 
Since, according to the condition of the box curve building, the segments $\mathrm{LM}$ and $\mathrm{BC}$ are reciprocally parallel, then $\mathrm{LQ}=\mathrm{MC}=a$ and the angles $\angle \mathrm{QBF}=\angle \mathrm{MLK}=15^{\circ}$. In the triangle $\mathrm{BQL}$, we find the angles at the vertices and use the sinuses theorem:

$\angle \mathrm{BQL}=105^{\circ}, \angle \mathrm{LBQ}=45^{\circ}, \frac{L Q}{\sin Q B L}=\frac{B L}{\sin B Q L}$.

We $\quad$ substitute: $\quad \frac{a}{\sin 45}=\frac{B L}{\sin 105}, \quad$ hence $\mathrm{BL}=\frac{1+\sqrt{3}}{2} a$

The distance $\mathrm{OO}_{1}=\mathrm{BF}=\mathrm{BL}=\frac{1+\sqrt{3}}{2} a$, $\mathrm{OO}_{3}=\mathrm{LT}=\sqrt{3} \cdot \frac{1+\sqrt{3}}{2} a=\frac{\sqrt{3}+3}{2} a$.

Then: $r=\frac{L}{2}-\mathrm{OO}_{1}=\frac{L}{2}-\frac{1+\sqrt{3}}{2} a=\frac{L}{2}+$

$$
\begin{aligned}
& -\frac{1+\sqrt{3}}{2}\left(\frac{L}{2}-H\right)=\frac{1-\sqrt{3}}{4} L+\frac{1+\sqrt{3}}{2} H, \\
& R=H+\mathrm{OO}_{3}=H+\frac{\sqrt{3}+3}{2} a=H+ \\
& +\frac{\sqrt{3}+3}{2}\left(\frac{L}{2}-H\right)=\frac{3+\sqrt{3}}{4} L-\frac{1+\sqrt{3}}{2} H .
\end{aligned}
$$

The circles' arches centers coordinates will be:

$$
\begin{aligned}
& \mathrm{O}_{1}=\left(-\frac{1+\sqrt{3}}{2} ; 0\right), \mathrm{O}_{2}=\left(\frac{1+\sqrt{3}}{2} a ; 0\right), \\
& \mathrm{O}_{3}=\left(0 ;-\frac{\sqrt{3}+3}{2} a\right)
\end{aligned}
$$

Since the this curve is a composite curve, then to describe it analytically we will use the equation of composite function given parametrically:

$$
\left\{\begin{array}{l}
\left\{\begin{array}{l}
x=r \cos t+\frac{1+\sqrt{3}}{2} a \\
y=\sin t
\end{array} \quad \text { at } \quad 0 \leq t<\frac{\pi}{3}\right. \\
\left\{\begin{array}{l}
x=R \cos t \\
y=R \sin t-\frac{3+\sqrt{3}}{2} a
\end{array} \text { at } \quad \frac{\pi}{3} \leq t \leq \frac{2 \pi}{3}\right. \\
\left\{\begin{array}{l}
x=r \cos t-\frac{1+\sqrt{3}}{2} a \\
y=r \sin t
\end{array} \text { at } \quad \frac{2 \pi}{3}<t \leq \pi\right.
\end{array}\right.
$$

where: $a=\frac{L}{2}-H$;

$$
\begin{gathered}
r=\frac{1-\sqrt{3}}{4} L+\frac{1+\sqrt{3}}{2} H ; \\
R=\frac{3+\sqrt{3}}{4} L-\frac{1+\sqrt{3}}{2} H .
\end{gathered}
$$

\section{Construction of reflections with the help of the podera and the orthotomics}

The sound and for light rays reflection principles are the same, therefore, first we shall consider light rays reflection (as more visually evident). The reflected beam shaping rule is well known from the school bench: at the reflection point $\mathrm{A}$, the reflection angle is found using the tangent and perpendicular (Fig. 3). When light is reflected, there appears a caustic, i.e. the envelope formed by a family of rays that do not converge at one point (curve 1).

However, geometrically this problem can be solved in a different way using such characteristic curves as podera (curve 1) and orthotomics (curve 2) in Figure 4.

In the $\mathrm{XIX}^{\text {th }}$ century, the German mathematician Jacob Steiner (1796-1863) showed the connection between podera and caustic and represented the curve as a reflection component. The given curve's podera relative to the point $\mathrm{P}$ embodies a set of bases of the perpendiculars dropped from the points $P$ to this curve's tangents. This curve's first descriptions appeared in the article by Gilles Pearson Roberval (1602-1675), 


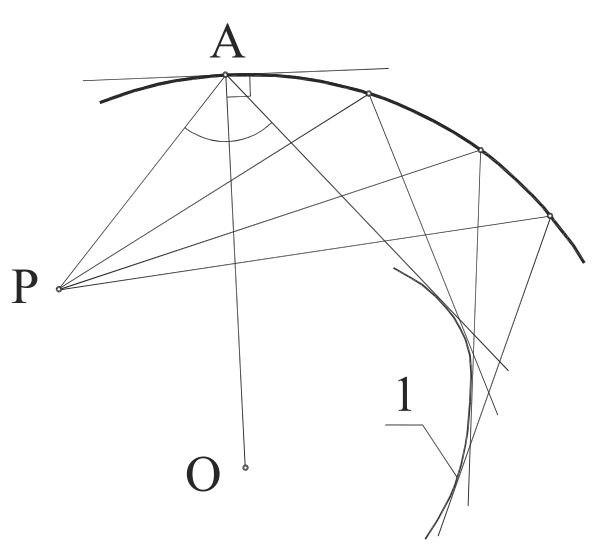

Fig. 3. Reflected rays path laying out

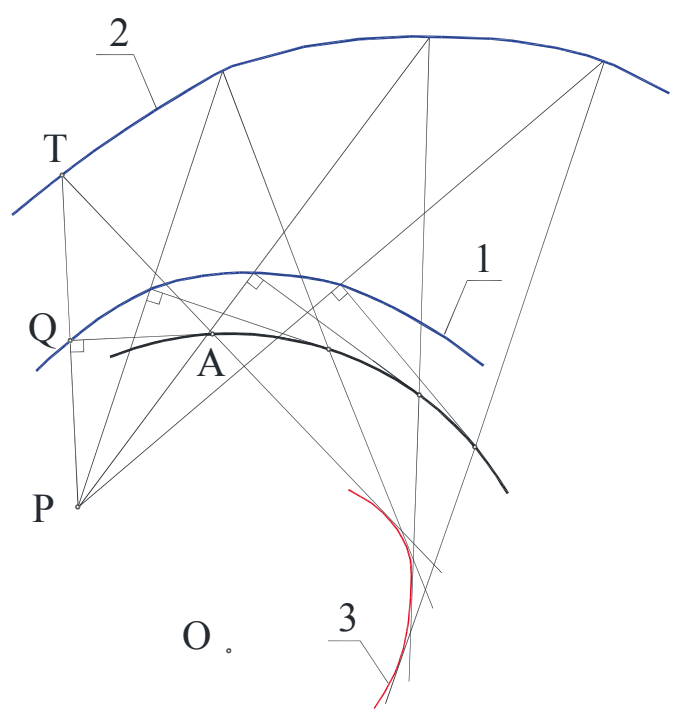

Fig. 4. Plotting the reflection with the use of the podera and orthotomics etc., and argues for the existence of antipoderas. Also he specifies the relationship between the curve, its podera and antipodera. These curves became the essence in his geometrical writings. He investigated these curves, classified them and tried to apply for mechanics' problems solving.

In the second half of the nineteenth century, about 400 articles were published in various fields of mathematics, fully or partially dealing with podera. Problems with this curve were considered in the geometry training course and even were included to the tasks of entrance examinations at the Polytechnic School in Paris.

Considering the increasing interest in this curve, the French mathematician and historian of mathematics, Olry Terkem, suggested to call it à-la Française, namely "la podaire".

When reflections building, there "arises" another curve, orthotomics. Each point of orthotomics is symmetrical to the light source relative to the podera of the reflecting curve. We can say that building the reflection with the orthotomics points facilitates the graphic part.

Let us consider both the podera who used in his methodorthogonal lines to construct tangents to conic sections and several spirals. Still, he did not emphasized podera anyway and did not develop a theory about that curve.

The next scientist who made a major contribution to this curve description is Colin Maclaurain (1698$-1746)$. In his work, published in 1718 , he draws attention to the curves represented by the geometric allocation of the base of the perpendicular dropped from the given point to the given curve's tangent. Maclaurin gave the first podera equation, showing the possibility of building another podera to the constructed one, and orthotomics "engaged" into reflection. From the point $\mathrm{P}$ (light source) we plot a perpendicular to the curve's tangent at point A (light reflection point). On the extended perpendicular PQ we plot the distance $\mathrm{PQ}=\mathrm{QT}$. The ray TA will be the ray reflected at point A. So, the curve 3 represents the built caustic.

\section{Equations of the podera and orthotomics for a circle in analytic geometry}

If the curve is given by an equation $y=f(x)$, where $x=t$, then the equations for the podera, orthotomics and caustics can be found at Pidgornyi and Kutsenko 
(1999). Since these formulas include derivatives, let we try to compose these equations for a circle using only analytic geometry. We represent the podera equation (curve 1 in Fig. 5) as a trajectory of the point $\mathrm{Q}$, i.e. point of two orthogonal lines intersection. The tangent to the circumference QA will "slide" along the circumference at the same time "pulling" the point of intersection with the straight line PQ, "fixed" at the given point $\mathrm{P}$; at that the two straight lines remain orthogonal at any time. Let we are given the following data:

point $\mathrm{P}\left(x_{0}, y_{0}\right)$,

circle $\left\{\begin{array}{l}x=r \cos t \\ y=r \sin t\end{array}\right.$

and an arbitrary point $\mathrm{A}(r \cos t, r \sin t)$.

Using the formula of a line in the plane $\left[y-y_{0}=k\left(x-x_{0}\right)\right]$, we compose the equation of QA tangent to the circle at the point $\mathrm{A}$ and the equation of line normal to the PQ tangent:

$$
\begin{gathered}
\text { QA: } y-r \sin t=-\operatorname{ctg} t(x-r \cos t) \\
\text { PQ: } y-y_{0}=\operatorname{tg} t\left(x-x_{0}\right)
\end{gathered}
$$

In order to find the coordinates for point $\mathrm{Q}$, it is necessary to solve the following equations system:

$$
\left\{\begin{array}{l}
y=r \sin t-\operatorname{ctg} t \cdot x+\operatorname{ctg} t \cdot r \cos t \\
y=\operatorname{tg} t \cdot x-\operatorname{tg} t \cdot x_{0}+y_{0}
\end{array}\right.
$$

Equating two equations in the system and having performed a series of transformations, we obtain the podera for the circle parametric equation:

$$
\left\{\begin{array}{l}
x=r \cos t+x_{0} \sin ^{2} t-\frac{1}{2} y_{0} \sin 2 t \\
y=r \sin t+y_{0} \cos ^{2} t-\frac{1}{2} x_{0} \sin 2 t
\end{array}\right.
$$

Now we compose the equation of the orthotomics (curve 2 in Fig. 5). The point T coordinates $\left(x_{T}, y_{T}\right)$ are found by the formulas:

$$
\left\{\begin{array}{l}
x_{T}=2 x_{Q}-x_{0} \\
y_{T}=2 y_{Q}-y_{0}
\end{array}\right.
$$

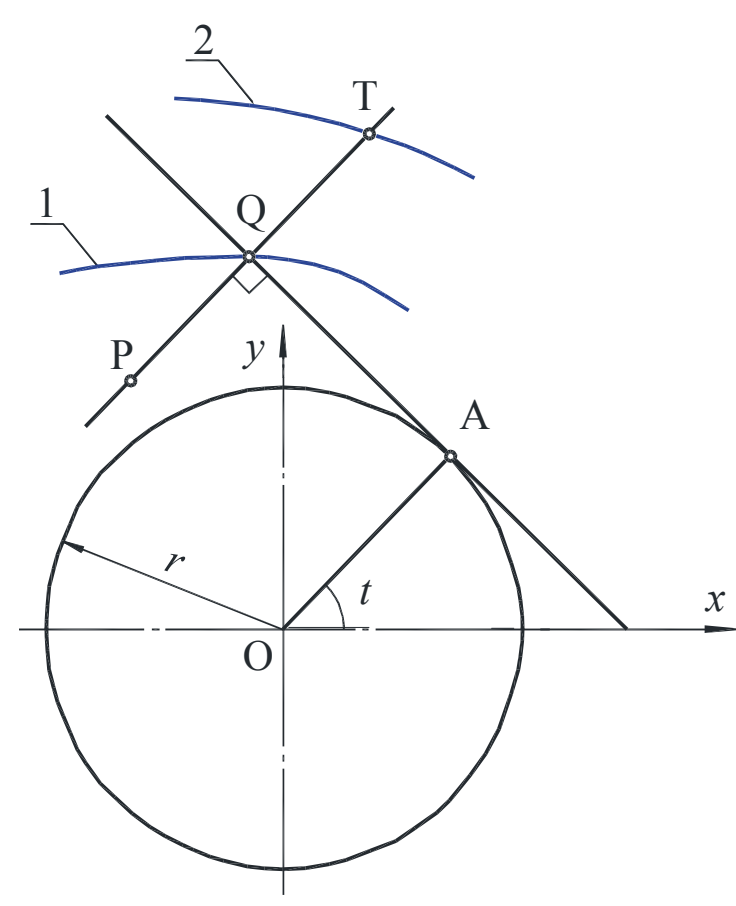

Fig. 5. Plotting the podera i orthotomics for the circle

where: $\left(x_{Q}, y_{Q}\right)$ represent $x$ and $y$ are from equation (2);

$x_{0}$ and $y_{0}$ are the coordinates of $\mathrm{P}$ point.

Substituting the coordinates into equation (2) and performing the transformations, we obtain the orthotomics for the circle parametric equation:

$$
\left\{\begin{array}{l}
x=2 r \cos t-x_{0} \cos 2 t-y_{0} \sin 2 t \\
y=2 r \sin t+y_{0} \cos 2 t-x_{0} \sin 2 t
\end{array}\right.
$$

As observed, the equations (2) and (3) can also be used for a circle, along to the other aforementioned equations.

\section{Analytical description of podera and orthotomics with reference to the threecentred curve}

To describe podera analytically, we use equations (1) and (2): 


$$
\left\{\begin{array}{l}
\left\{\begin{array}{l}
x=r \cos t+x_{0} \sin ^{2} t-\frac{1}{2} y_{0} \sin 2 t+\frac{1+\sqrt{3}}{2} a \\
y=r \sin t+y_{0} \cos ^{2} t-\frac{1}{2} x_{0} \sin 2 t
\end{array} \text { at } \quad 0 \leq t<\frac{\pi}{3}\right. \\
\left\{\begin{array}{l}
x=R \cos t+x_{0} \sin ^{2} t-\frac{1}{2} y_{0} \sin 2 t \\
y=R \sin t+y_{0} \cos ^{2} t-\frac{1}{2} x_{0} \sin 2 t-\frac{\sqrt{3}+3}{2} a
\end{array} \text { at } \quad \frac{\pi}{3} \leq t \leq \frac{2 \pi}{3}\right. \\
\left\{\begin{array}{l}
x=r \cos t+x_{0} \sin ^{2} t-\frac{1}{2} y_{0} \sin 2 t-\frac{1+\sqrt{3}}{2} a \\
y=r \sin t+y_{0} \cos ^{2} t-\frac{1}{2} x_{0} \sin 2 t
\end{array} \text { at } \frac{2 \pi}{3}<t \leq \pi\right.
\end{array}\right.
$$

To describe orthotomics analytically, we use equations (1) and (3):

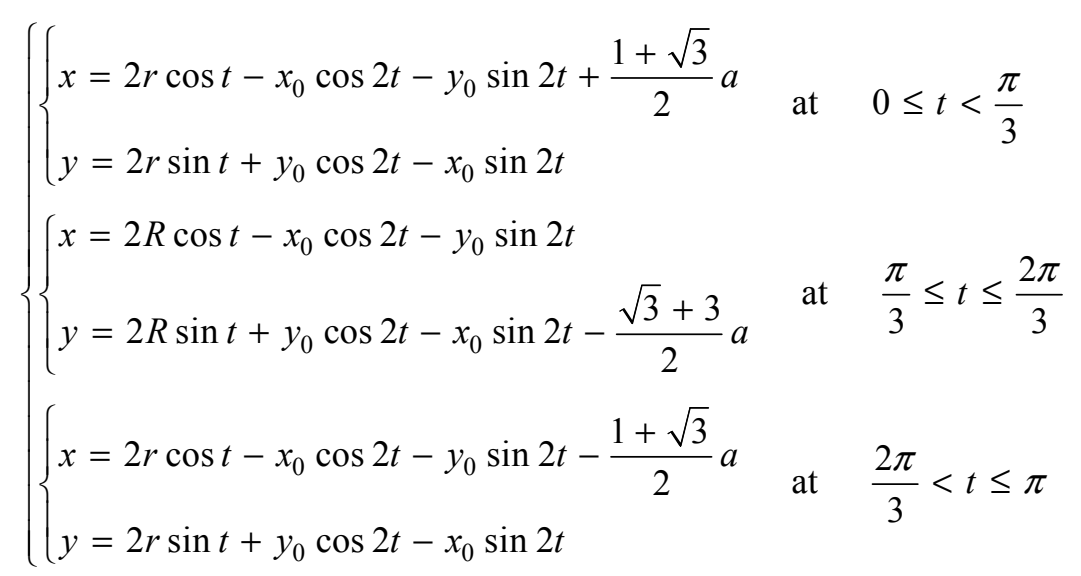

where: $a=\frac{L}{2}-H$;

$$
\begin{aligned}
& r=\frac{1-\sqrt{3}}{4} L+\frac{1+\sqrt{3}}{2} H ; \\
& R=\frac{3+\sqrt{3}}{4} L-\frac{1+\sqrt{3}}{2} H .
\end{aligned}
$$

\section{Application}

For geometric modeling of reflected sound in the threecentred arch, we selected the existing vault, this one of the Yusupov Palace Trapeznaja Palata (Fig. 6). Unfortunately, we do not have the exact dimensions of this room, so being limited with measuring the propor-

tions in AutoCAD we take the supposed dimensions ratio as $H=0.363 L$.

Substituting this size into the formula (1) and its components, we obtain an analytical description of the threecentred arch of Trapeznaja Palata: 


$$
\begin{gathered}
r=\frac{1-\sqrt{3}}{4} L+\frac{1+\sqrt{3}}{2} H=0.313 L ; \\
R=\frac{3+\sqrt{3}}{4} L-\frac{1+\sqrt{3}}{2} H=0.687 L ; \\
\left\{\begin{array}{l}
\left\{=\frac{L}{2}-H=0.137 L ;\right. \\
\left\{\begin{array}{l}
x=0.313 L \cos t+0.187 L \\
y=
\end{array} \quad \text { in } t \quad \text { at } \quad 0 \leq t<\frac{\pi}{3}\right. \\
y=0.687 \sin t-0.324 L \\
\left\{\begin{array}{l}
x=0.313 \cos t-0.187 L \\
y=0.313 \sin t
\end{array} \quad \text { at } \quad \frac{\pi}{3} \leq t \leq \frac{2 \pi}{3}\right.
\end{array}\right. \\
\end{gathered}
$$

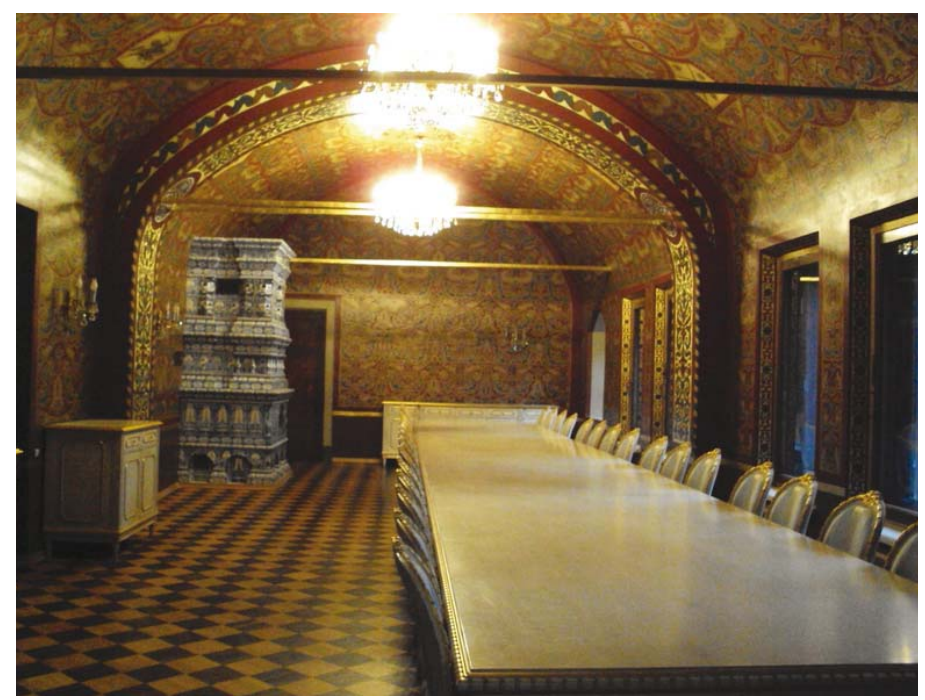

Fig. 6. Trapeznaja Palata, Yusupov Palace, Moscow, Russia

(http://photo.qip.ru/users/gguide/200657310/?mode=xlarge\&sort=rating\&page=2)

Now we consider two variants of sound reflection, when the speaking person is in the center of the room and when staying near the wall. The sound source height is taken based on the dimensions of the door located on the photo's right $\left(\mathrm{P}_{1}-\right.$ sound source is in the center, $\mathrm{P}_{2}$ - sound source is near the wall, Fig. 7).

We can easily compose the equations of podera (7) and orthotomics (8) giving the coordinates $P_{1}(0,-0.06 L)$ : 


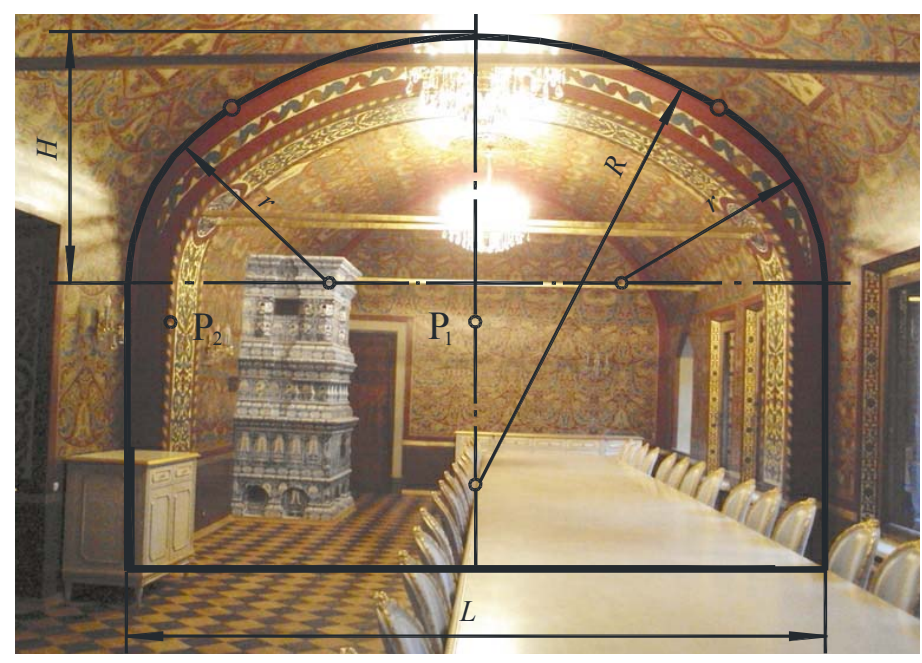

Fig. 7. Trapeznaja Palata layout

$$
\begin{aligned}
& \left\{\begin{array}{l}
\left\{\begin{array}{l}
x=L(0.313 \cos t+0.03 \sin 2 t+0.187) \\
y=L\left(0.313 \sin t-0.06 \cos ^{2} t\right)
\end{array} \text { at } \quad 0 \leq t<\frac{\pi}{3}\right. \\
\left\{\begin{array}{l}
x=L(0.687 \cos t+0.03 \sin 2 t) \\
y=L\left(0.687 \sin t-0.06 \cos ^{2} t-0.324\right)
\end{array} \text { at } \quad \frac{\pi}{3} \leq t \leq \frac{2 \pi}{3}\right. \\
\left\{\begin{array}{l}
x=L(0.313 \cos t+0.03 \sin 2 t-0.187) \\
y=L\left(0.313 \sin t-0.06 \cos ^{2} t\right)
\end{array} \text { at } \quad \frac{2 \pi}{3}<t \leq \pi\right.
\end{array}\right. \\
& \left\{\begin{array}{l}
\left\{\begin{array}{l}
x=L(0.626 \cos t+0.06 \sin 2 t+0.187) \\
y=L(0.626 \sin t-0.06 \cos 2 t) \\
\left\{\begin{array}{l}
x=L(1.374 \cos t+0.06 \sin 2 t) \\
y=L(1.374 \sin t-0.06 \cos 2 t-0.324)
\end{array}\right.
\end{array} \text { at } \quad \frac{\pi}{3} \leq t \leq \frac{2 \pi}{3}\right. \\
\left\{\begin{array}{l}
x=L(0.626 \cos t+0.06 \sin 2 t-0.187) \\
y=L(0.626 \sin t-0.06 \cos 2 t)
\end{array}\right.
\end{array} \text { at } \quad \frac{2 \pi}{3}<t \leq \pi\right.
\end{aligned}
$$

In Figure 8 the plotted curves are: the podera (curve 1), the orthotomics (curve 2), and reflected rays with a caustic (curve 3 ) for the case where the sound source is at point $P_{1}$. The podera almost merges with the circle, since the sound source is close to the center of the arcs of the threecentred curve, and the orthonomics resembles a threecentred arch, doubled in size. It can be seen from the drawing that the sound "returns" to the speaker. In Figure 9 both the podera (curve 1) and orthotomics (curve 2) represent a curve composed of Pascal's snail parts. In this case, the sound source is at the wall $\left(\mathrm{P}_{2}\right)$, and it can be clearly seen that the sound, reflected from the roof (some rays reflected several times), passes along the ceiling and concentrates on the opposite side, repeating the "whispering gallery" effect. 
Kernytskyy, I. \& Nikitenko, O. (2018). Geometric modeling of reflected sound waves in the threecentred arch. Acta Sci. Pol. Architectura, 17 (1), 13-23. doi: 10.22630/ASPA.2018.17.1.2.

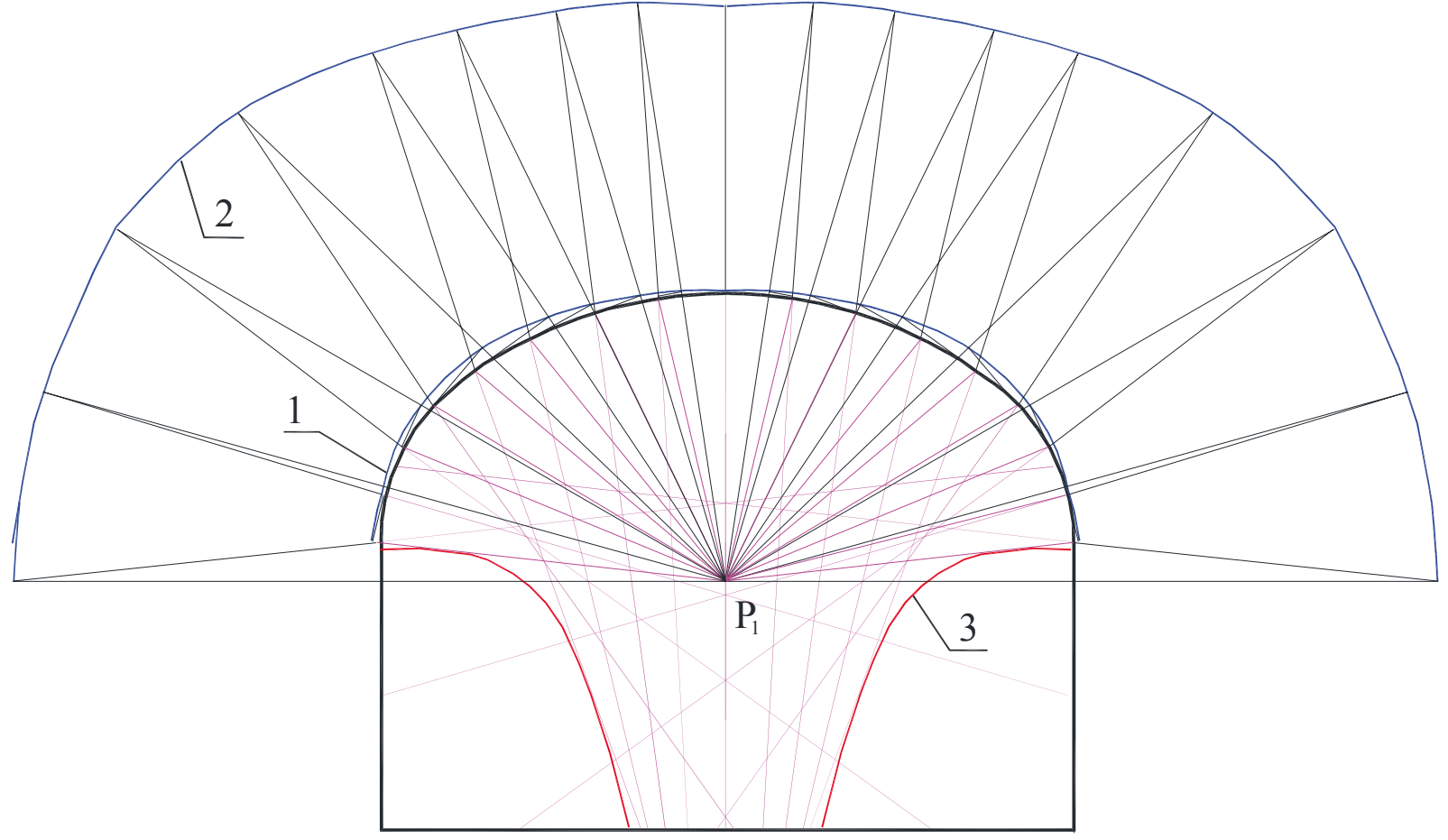

Fig. 8. Plotting the podera $i$ orthotomics for the threecentred arc when the sound source is in the center

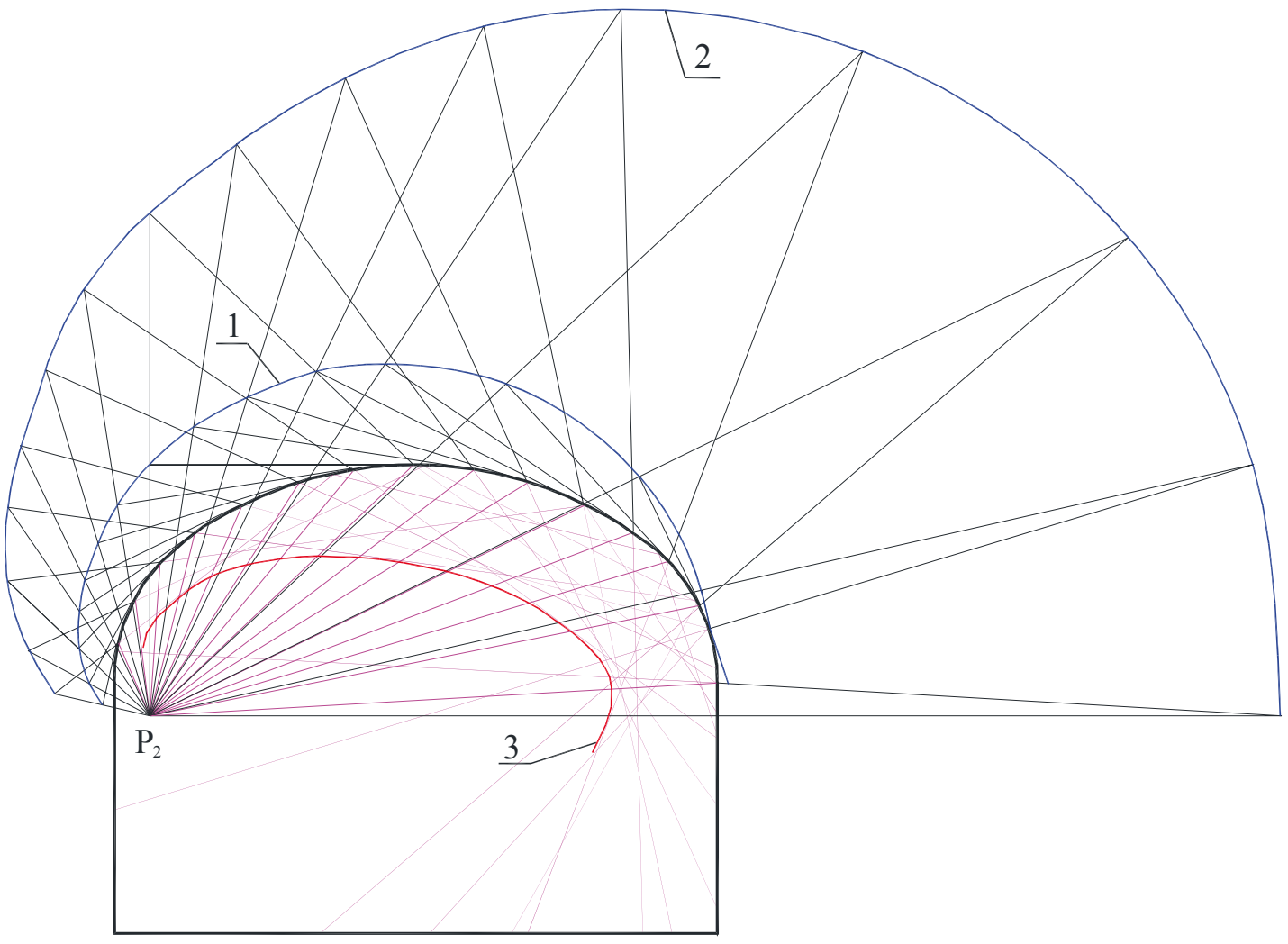

Fig. 9. Plotting the podera i orthotomics for the threecentred arc when the sound source is near the wall 


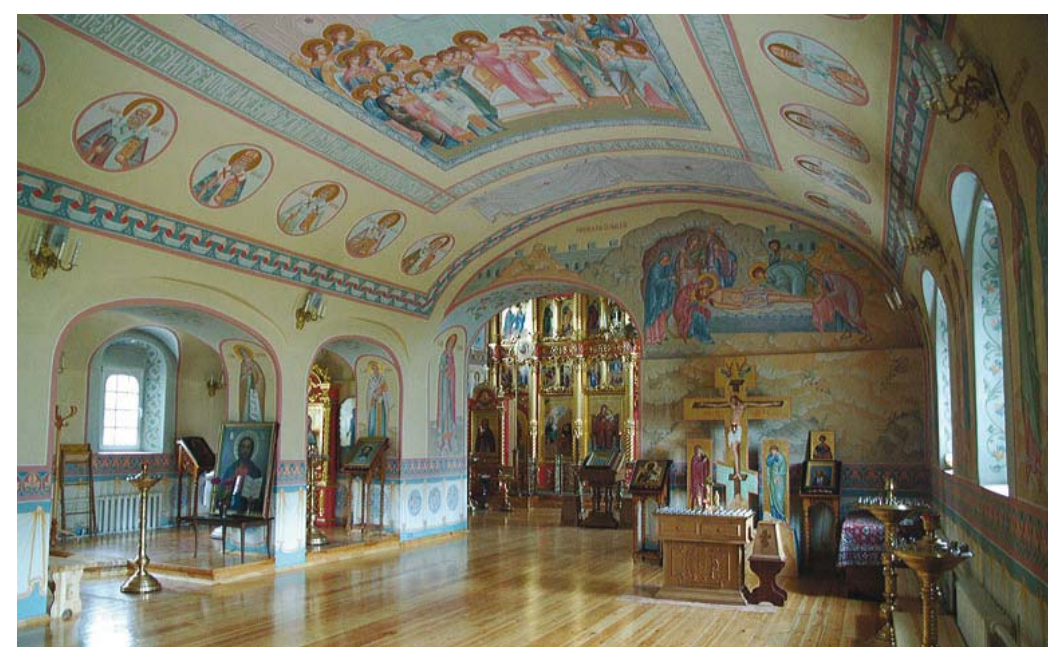

Fig. 10. Threecentred arch of the Uspenskaya Church, Nizhny Novgorod, Russia

(http://temple_architecture.academic.ru/190/коробовый_свод)

\section{CONCLUSIONS}

The cylindrical arches have been widely used in the ancient architecture, but the ancient architects, despite the ignorance of sound reflection physical laws, have empirically come to the conclusion that it is more expedient to use threecentred arches for small rooms (Fig. 10). In this case, the location's acoustic properties are better than when cylindrical arches since in the latter the sound "collects" under the vault, and in the threecentred one the sound "returns" to the speaker. The threecentred arch acoustics allows easily filling the entire small room with sound.

\section{REFERENCES}

Engel, Z., Engel, J., Kosała, K. \& Sadowski, J. (2007). Podstawy akustyki obiektów sakralnych. Radom: Instytut Technologii Eksploatacji - Państwowy Instytut Badawczy.

Engineering drawing (1983). Ed. A.V. Potishko. Kyiv: Budivelnyk.
Klemma, P. (2008). Budownictwo ogólne. T. 2. Fizyka budowli. Warszawa: Arkady.

Lewis, M. (2008). Elementy stylu architektonicznego. Warszawa: Arkady.

Niemas, M. \& Nowicka, E. (2006). Kształtowanie warunków pogłosowych w obiektach sakralnych. Zeszyty Naukowe Politechniki Białostockiej, Budownictwo, 30, 321-328.

Niemas, M., Sadowski, J. \& Engel, Z. (2000). Wpływ rozwiązań materiałowo-konstrukcyjnych na kształtowanie akustyki wnętrz sakralnych. W III Międzynarodowa Konferencja Naukowo-Techniczna „Budownictwo sakralne i monumentalne”, Białystok, 169-180.

Pidgornyi, O. \& Kutsenko, L. (1999). The description of podera, orthotomic and caustic as elements of the reflection system. The works of Tavria State Agrotechnical Academy, 4 (10), Melitopol, 14-18.

Rozborski, R. (2006). Wykonywanie sklepień, nadproży istropów murarskich. Poradnik dla ucznia. Radom: Instytut Technologii Eksploatacji - Państwowy Instytut Badawczy.

Tutunnikov, S. (2013). The description of the components of the reflection system with classical curves. Energy Efficiency in Construction and Architecture, 5, 130-136. 


\section{MODELOWANIE GEOMETRYCZNE ODBITYCH FAL DŹWIĘKOWYCH W SKLEPIENIU KOSZOWYM}

\section{STRESZCZENIE}

Ostatnimi czasy obserwuje się szeroko prowadzone badania nad systemami refleksyjnymi w ogrzewaczach cieplnych, inżynierii słonecznej i akustyce. Stosowane w tych technologiach reflektory są konstrukcjami budowlanymi na bazie klasycznych krzywych. Proces odbijania fal determinowany jest przez krzywe, takie jak podera, ortotomika czy kaustyka. Celem niniejszej pracy było znalezienie analitycznego opisu krzywej koszowej, jej podery oraz ortotomiki, jak również zaprezentowanie zależności geometrycznych modeli istniejącego sklepienia w kształcie krzywej koszowej. Analityczny opis takich krzywych przeprowadzono, stosując geometrię analityczną na płaszczyźnie. W rezultacie otrzymano wzory analityczne podery i ortotomiki dla okręgu, a następnie dla samej krzywej koszowej. W celu przeprowadzenia modelowania geometrycznego odbitego dźwięku na sklepieniu koszowym wykorzystano istniejące sklepienie obiektu Trapieznaja Pałata w Pałacu Jusupowa (Moskwa, Federacja Rosyjska). W pracy przedstawiono skonstruowany graficznie w edytorze AutoCAD projekt samego sklepienia, podery, ortotomiki i kaustyki w odniesieniu do jego części koszowej. Uzyskane wyniki wskazują na zaawansowaną wiedzę posiadaną przez dawnych architektów, którzy potrafili prawidłowo zastosować ją w praktyce.

Słowa kluczowe: sklepienie koszowe, podera, ortotomika, kaustyka, obwiednia 